\title{
THE PORTUGUESE CONTRIBUTION TO SOUTH AFRICAN TOPONYMY
}

Dr. P.E. Raper*

\begin{abstract}
In hierdie artikel weergee dr. Raper, verbonde aan die Onomastiese Navorsingsentrum van die RGN, die reise van die onverskrokke Portugese seevaarders, ondermeer Dias en Da Gama, en die plekname wat hulle agtergelaat het. $\mathrm{Na}$ 'n deeglike bespreking van 'n paar van hierdie name kom dr. Raper tot die gevolgtrekking dat hierdie name, op grond daarvan dat hulle die eerste name in suider Afrika was wat deur Europeërs nagelaat is, van belang is vanuit 'n kulturele, historiese en linguïstiese oogpunt.
\end{abstract}

Names are a vital part of language. They not only facilitate communication but also make it possible for us to orientate ourselves in the world in which we live. Names identify entities and distinguish them from others. In contrast to 'ordinary' words in a language, names are used freely in other languages and thus have a greater international impact. Yet in the first place, at the time of their bestowal, they were derived from a specific language and reflect the culture, life-style and attitudes of the people who bestowed them. Names constitute a most important historical record and form a valuable component of cultural heritage. They may be regarded as a monument to the pioneers who gave them.

At the same time place names are of vital strategic importance in the geographical framework within which military activities take place.

Portuguese place names are among the oldest European names borne by geographical features in southern Africa. For the most part they date from the late 15th and early 16 th centuries. At that time Portuguese navigators, then the most itrepid mariners of Europe, were seeking a sea-route to India. They had already worked their way down the west coast of Africa and had discovered and occupied the islands of the north-western coast, from the Azores to the Cape Verde group. The extent of the African continent, and the situation of its southernmost extremity, were still unknown. Cape Cross was the furthest point to have been reached by 1485 .

In 1486 King John II sent Bartholomeu Dias with three small ships on a new exploratory expedition. Having passed Cape Cross, Dias called at Angra dos Ilhéus, 'the bay of islets', later designated Angra Pequena or 'little bay', now known as Lüderitzbucht. Continuing southwards along the coast he met with contrary winds which necessitated frequent tacks or changes in direction.

Having then been blown out to sea and driven eastwards, Dias found himself at the presentday Mossel Bay, which he named Angra dos Vaqueiros, 'bay of herdsmen'. A later expedition named it Anguada de Sâo Brás, 'watering-place at St Blaize', after the saint to whom the day is dedicated on which Dias first saw it.

On the return voyage Dias in 1487 discovered the headland he named Cabo Tormentoso or Cabo das Tormentas, 'cape of storms', subsequently renamed Cabo da Bôa Esperança and still today known as Cape of Good Hope.

Emanual, who succeeded King John II after his death in 1495, equipped a small fleet and entrusted it to Vasco da Gama who in 1497 set sail, attempting to discover a sea-route to India via Africa. After a voyage of five and a half months he reached St. Helena Bay, which he named.

His next port of call was Mossel Bay, after which he reached the present-day Pondoland coast on Christmas Day. For this reason he named it Terra do Natal. Having then touched at Mozambique and Melinda, Da Gama sailed to Calicut, thus achieving the object after which Portugal had for so long striven.

Subsequent voyages by Portuguese mariners added to the nomenclature. It will be noticed, however, that these names are mainly limited to the coastal belt of the subcontiment. There are several reasons for this. The early explorers had set out with a definite purpose in mind, namely to discover a new sea-route to the Orient with its vast wealth. They probably had no intention of achieving anything more than opening up new channels of trade and commerce for Portugal. Moreover, the inhospitable terrain and, particu- 
larly, the hostile disposition of the indigenous peoples, probably deterred them from attempting to penetrate into the interior.

The fact that names bestowed by Portuguese in South Africa were generally limited to coastal and maritime features, is reflected in the generic terms occurring in the names: aguanda, 'watering place'; baia or bahia, 'bay'; cabo, 'cape'; ilha, 'island'; penedo, 'rock'; pic, 'peak'; ponta, 'point'; praia, 'shore'; rio, 'river'.

A fair number of names bestowed by the Portuguese have survived in their original form, while others have been adapted, translated (wholly or in part), or supplanted. Hybrid forms, with part of the name Portuguese and part English or Afrikaans, are also encountered.

A perusal of Portuguese place names in southern Africa indicates that nomenclature was motivated by several considerations, primarily geographical, religious, social, and historical.

As may be expected, many place names were based on the appearance of the entity concerned, the presence there of some prominent feature, climatic condition prevailing, and so forth. A Mesa, 'the table', described the flattopped mountain now known as Table Mountain. It also bore the Portuguese name Tabua do Cabo, 'table of the Cape'. Algoa Bay, a name now borne by the inlet on which the city of Port Elizabeth is situated, was at various times applicable to several different bays along the coast, including the present-day Plettenberg Bay. It is derived from the word lagoa, 'marsh', or 'morass'. The name Delagoa is said to be based on this same word. Algoa Bay has another Portuguese name, Bahia da Roca or 'rock bay'; it was given by Dias in 1576 .

Plettenberg Bay, too, had another Portuguese name, namely Baia Formosa, meaning 'beautiful bay', later anglicized to Formosa Bay. The Krakeel River Peak took its name from this bay and was known as Formosa Peak, also Peak Formosa, from Pico Formoso, Pic Fermosa, etc. An interesting popular etymological adaptation of this name has resulted in the 'Afrikaans' name Van der Mosesberg.

Angra dos Ilheus, 'bay of small islands', has been mentioned above as an early name for Lüderitzbucht, as has its other Portuguese name, Angra Pequena or 'small bay'.
Cabo das Serras means 'cape of mountains'. This descriptive name was given to the promontory where the mountains end which start at the Cape of Good Hope. Cape St Francis also bore this name.

Cape Recife, near Port Elizabeth, takes its name from Cabo de Recife, 'cape of reefs', while IIheus Caos, meaning 'flat islands', was given to a group of islands in Algoa Bay. When the British ship Doddington was wrecked there in 1755 , the survivors named these the Bird Islands, after the many seafowl, particularly gannets, they saw there.

Another island which takes its name from birds, though indirectly, is Ilha Branca, 'white island', presumably after the colour of the guano. In 1601 the Dutch navigator Joris van Spilbergen called the island Elizabeth Island, but four years later the name was changed by Sir Edward Michelburne to Coney Island, on account of the many seals and conies there. Today the island is known in its translated form as Dassen Island.

In 1486 Dias named an island in Algoa Bay Ilheu da Santa Cruz. Some of his followers, however, gave it the name of Penedo das Fontes, from penedo, 'rock', fontes 'a spring'. It seems that there were two springs of fresh water on the island. In the vicinity of the Kowie River there are several rocks, known as Fountain Rocks, and some consider this name to be a direct descendant of the Portuguese name Penedo das Fontes. The island in Algoa Bay later became known as St Croix.

Green Point is said to be the second oldest English place name in South Africa, having been bestowed in 1675. This point was known by the Portuguese name Ponta da Praia, 'point of shores', 'point with a beach'.

Ponta Espinhosa, 'thorny point', presumably refers to the sharp rocks at or in the sea there. This name could have referred to either the pesentday Bok Point or Cape Hangklip.

Serra Branca, a name meaning 'white mountain', was applied to what is today known as the Zuurberg or Addo Heights, while Soco Reefs has a name derived from the Portuguese name Ilheus Siccos, 'arid islands'.

A final descriptive name to be mentioned is Terra dos Bramidos, 'land of the roaring of the 
sea'. This designation was applied to the Atlantic coast south of the Orange River Mouth.

Besides physical descriptions of the named entities or of geographical features in the vicinity, climatological considerations are reflected in the toponymy. Cabo Tormentoso, 'stormy cape', or Cabo das Tormentas, 'cape of storms', was the first name of Cape of Good Hope, Terra dos Trovoadas, 'land of thunderstorms', was an appellation applied to the Langkloof which is situated between the Kammanassie and Kouga ranges in the north and the Tsitsikamma Mountains in the south.

Finally, reference is made to creatures encountered. Walvis Bay bears a name referring to whales; it is translated from the Portuguese Baia das Baléas, 'bay of whales'. Golfo da Baleia, with the same origin, was the designation applied to the vicinity of the present-day Lüderitzbucht. It is also found as Golfo de Balena and Gulf d'Baleines.

A large number of Portuguese place names reflects the devout Catholic religious beliefs of these intrepid mariners. The name of the province of Natal is derived from Terra do Natal, 'land of the birth (of Christ)'. It was bestowed by Vasco da Gama in 1497 because it was on 25 December, Christmas Day, that he passed this coast.

On the west coast is a related name, Golfo da Conceiçâo, a shortened form of Golfo de Santa Maria da Conceoçâo. The reference is to the Immaculate Conception of Mary, mother of Jesus Christ. At present this bay is known as Walvis Bay.

Saints' names often feature in place names. These were generally bestowed because it was on the name-day of the particular saint that the place was reached. Aguada de Sâo Bras means 'the watering-place of St Blaize'; it was here that Vasco da Gama in 1497 went ashore to replenish his supply of fresh water, on the day dedicated to St Blaize. The bay was renamed Mosselbaai by the Dutch in 1601 because all they could find to eat were mussels (Dutch mossen). The promontory at Mossel Bay was accordingly named Cabo Sâo Bras and it still today bears the name, albeit in the translated form of Cape St Blaize.

Cape St Francis and St Francis Bay also have translated names, respectively from Cabo de
Sâo Francisco and Baia de Sâo Francisco. The latter name was given by Manuel Perestrelo in 1575 to modern-day Jeffreys Bay, which is included in St Francis Bay.

Ponta de Sâo Brandâo was the name Dias gave to the southernmost extremity of the African continent. It means 'point of St Brandon', whose name-day is 16 May. The English toponym Point St Brandon has also been documented; at present the name it bears is Cape Agulhas.

The Mthathe River, to which Umtata owes its name, was named Rio de Sâo Thomé by the Portuguese, 'river of St Thomas'. St Sebastians Bay was dedicated to that saint by Perestrelo, while St Helena Bay was named by Vasco da Gama.

Lake St Lucia, La Lucia and similar names honour that saint; the Portuguese form of the name is Santa Luzia. The Tugela River once bore the name Rio S. Luzia.

St James is honoured by the early Portuguese name for the Berg River, namely Santiago, also occurring as S. Tiago, Samtiaguo and Santiaguo.

Port St John was indirectly named after a saint; the Galleon Sâo Joâo was wreched at the mouth of the Mtamvuna River on 18 June 1552, and it was in commemoration of that event that the name was bestowed.

Cape Padrone, too, bears a name indirectly derived from that of a saint. A padrâo, i.e. a stone cross, pillar or monument, was erected there by Dias and dedicated to St Gregory, as a consequence of which the name Padrâo de San Gregorio came to be applied to it. It was from this that the modern-day name was derived.

Socially motivated names are those which refer to people. In this category two types may be identified here, namely those referring to individuals and those referring to groups. Since the early Portuguese mariners did not come into contact with groups of people on many occasions, the number of toponyms of the latter type is limited.

Angra dos Vaqueiros, 'bay of herdsmen', was so named by Bartholomeu Dias because of the pastoral nature of the people and the large droves of cattle they kept. A subsequent expedition named the bay Aguada de Sâo Bras, a 
name which, as has been noted above, was superseded by Mossel Bay. The name Rio dos Vagueiros, 'river of herdsmen', was given to the Gourits. angra das Vacas or 'bay of cows', now Vlees Bay or Flesh Bay, and Cabo das Vacas, 'cape of cows', are also names referring to the keeping of cattle. Terra da Boa Gente, 'land of good people', was the name Da Gama bestowed on the area near the mouth of the Limpopo River. The coastal area south of Delagoa Bay was called Terra dos Fumos by him, a name said to mean 'land of petty chiefs'.

Names referring to or commemorating individuals are more numerous. In some instances a specific occurrence involving a person was the motivating factor leading to the name. Thus, for example, Aguada de Saldanha commemorates Admiral Antonio de Saldanha and means the water-place of Saldanha'. However, it was not the fact that he took in water there in 1503 that gave the place its name as much as the fact that he and his men were attacked by Khoekhoen ('Hottentots'). The place thus designated was the pesent-day Table Bay, and for nearly a century it was known as such. Then, however, the name was translated to the present Saldanha Bay.

Bartolomeu Dias is commemorated in the name Dias Point, a rocky promontory at the southwestern extremity of Lûderitz Bay, where Dias erected a padrâo to St James on 25 July 1488; Da Gama Park, a township in the district of Simon's Town, was so named in honour of Vasco da Gama.

Cape Infanta, on the estuary of the Breede River, takes its name from Joâo de Infante, captain of Dias's second caravel. The Portuguese name from which it is derived, was Cabo de Infante. Also named after him was rio de Infante. It is said that infante was the first to leap ashore, but precisely where that happened is uncertain. Rio do Infante has been variously identified as the Great Fish River, the Kowie, the Keiskamma, and the Oliphants.

Several names with Portuguese elements were given after non-Portuguese people. Isla de Cornelia and Isla d'Elizabeth were both named by Joris van Spilbergen, the Dutch mariner. His mother's name was Cornelia, and that of his wife was Elizabeth. These two islands are today known as Robben Island and Dassen Island respectively.
Then there are Portuguese names in the interior, given in comparatively recent times. Albasini and the Albasini Dam, at the foot of the Soutpansberg range in Transvaal, were named after Joâo Albaşini. He was Vice-Consul for Portugal and Superintendent of the African people in the Soutpansberg under the South African Republic. Several clans of the Magwamba accepted him as their chief.

Also in Transvaal is Machadodorp, a town about $25 \mathrm{~km}$ east of Belfast. It waas named in honour of Joachim Jose Machado, Governor-General of Mozambique, who played a prominent role in the survey of the railway line from Pretoria to Lourenco Marques, now Maputo.

In conclusion, the historical motivation for naming can be discerned in designations based on occurrences. On his voyage southward in 1488 , Dias was compelled by contrary winds to make many tacks or changes of direction. When he at last found anchorage in an inlet, he named it Angra das Voltas, 'bay of tacks'.

False Bay takes its name from Cape False, Portuguese Cabo Falso, an old name for Cape Hangklip. It was thus named because early navigators sailing westwards mistook it for Cape Point and turned north too soon.

Cape of Good Hope is an important name in South Africa, referring as it does not only to the southernmost tip of the Cape Peninsula but also inter alia to the modern Cape Province. The promontory was, as has been indicated, designated Cabo Tormentoso by virtue of the foul weather encountered there. Subsequently it was renamed, either by Dias himself or by King John, Cabo da Boa Esperança, 'cape of good hope', because the doubling of the Cape gave hope of a sea-route to the East.

Cape Agulhas takes its name from the Portuguese form Cabo das Anguillas which means 'cape of the needle'. This does not refer to the needle-like quality of reefs there, as has been thought, but to the fact that the compass-needle showed no magnetic declination there but pointed directly north. Consequently other names of this headland include Cape of Compasses, Needles of the Compass, and The Needles.

Port St Johns takes its name from the fact that the galleon Sâo Joâo was wrecked nearby on 18 
June 1552; St John as a translation of the name of the ship.

From what has been stated above, it may be seen that Portuguese place names in Southern Africa are of importance from a cultural, historical and linguistic point of view. They were the first names in Southern Africa bestowed by Europeans; they give us an insight into the customs and beliefs of those early mariners; and historical and linguistic facts can be deduced by studying the names and ther variants as encountered in different sources. The names were also aesthetically pleasing, being euphonious and accurately descriptive. We at the southern tip of the African continent are the richer for those Portuguese place names which have survived, albeit in adapted form; we are the poorer for having lost many, either directly or through supplantation
* Dr P.E. Raper is attached to the Onomastic Research Centre, Human Sciences Research Council.

\section{Bibliography}

Axelson, Eric. 1940. South-East Africa, London: Longmans, Green. Botha, C.G. 1927. Place Names in the Cape Province. Cape Town: Juta.

Du Plessis, E.J. 1973. 'n Ondersoek na die Oorsprong en Betekenis van Suid-Afrikaanse Berg- en Riviername, Kaapstad: Tafelberg.

Nienaber, P.J. 1973. Suid-Afrikaanse Pleknaamwoordeboek, Deel l, 2de druk. Kaapstad: Tafelberg.

Pettmann, Rev. C. 1931. South African Place Names Past and Present. Queenstown: Daily Representative.

Raper, P.E. 1975. Portuguese Place Names in South Africa. In: M. Valkhoff, ed. Miscelânea Luso-Africana. Lisbon: Junta de Investigaçôes Cientificas do Ultramar, 265-291.

Raper, P.E. 1987. Dictionary of Southern African Place Names, Johannesburg: Lowry.

Raven'Hart, R. 1967. Before Van Riebeeck. Cape Town: Struik.

Ravenstein, E.G. 1898. Voyage of Vasco da Gama 1497-1499. London: printed for Hackluyt Society.

Skead, C.J. 1973. Zoo-historical Gazetteer Grahamstown: Cape Provincial Museums. 